ORIGINAL ARTICLE

\title{
Use of biodiesel co-products (Glycerol) as alternative sources of energy in animal nutrition: a systematic review
}

\author{
Uso de co-productos de biodiesel (Glicerol) como fuentes alternativas de energía \\ en la alimentación animal: una revisión sistemática
}

\author{
VO Silva ${ }^{a^{*}}$, E Lopes ${ }^{\text {a }}$ EF Andrade ${ }^{a}$, RV Sousa ${ }^{a}$, MG Zangeronimo ${ }^{\text {a }}$ LJ Pereira ${ }^{\text {a }}$ \\ aDepartment of Veterinary Medicine, Physiology and Pharmacology Area, \\ Federal University of Lavras, Lavras, Minas Gerais, Brasil.
}

\begin{abstract}
RESUMEN
El reciente aumento en el uso de biodiesel en Brasil y en el extranjero, junto con la disponibilidad de gran cantidad de su residuo, el glicerol, ha generado un gran interés en el uso de este co-producto de varias maneras, entre ellas su aplicación en la alimentación animal. El uso de glicerol en la formulación de dietas despierta interés inmediato para obtener un producto rico en energía y alta eficiencia de utilización por los animales. El objetivo de este estudio fue evaluar los efectos del uso de la glicerina resultante de la producción de biodiesel como suplemento energético en la producción de alimentos para animales, buscando establecer protocolos adecuados para cada especie a partir de estudios anteriores. En los trabajos analizados, hubo estudios con cerdos, vacas, toros, ovejas, gallinas ponedoras y pollos de engorde. Del análisis realizado se puede inferir que el glicerol es un ingrediente alimenticio de remplazo adecuado en dietas en animales de producción.
\end{abstract}

Palabras clave: alimentación, ingrediente alimentario, producción animal, desempeño.

\section{SUMMARY}

The recent surge in the use of biodiesel in Brazil and abroad, coupled with the availability of large amounts of glycerol, are generating interest in the use of this co-product in several ways, such as its use in animal feed. The use of glycerol in the formulation of diets caused immediate interest to obtain a highly efficient energy rich product to use in animal production. The aim of this study was to evaluate the effects of the use of glycerol resulting from biodiesel production as an energy supplement in animal feed, as well as establishing appropriate protocols for each species based on previous studies. Most of them using pigs, cows, bulls, sheep, laying hens and broilers. It was possible to infer from these studies that glycerol was a food ingredient suitable for replacement in diets of different animal species.

Key words: diet, food ingredients, animal production, performance.

\section{INTRODUCTION}

Brazil is a country with great diversity of oilseed crops for biodiesel production and it has advanced technology and industrial structure with a high potential for the development of biofuels. Resolution $\mathrm{N}^{\circ}$. 6/2009 of the National Energy Political Council (ANP 2009) requires the mandatory addition of $5 \%$ of biofuel to diesel oil sold throughout the country since January 2010. According to the National Petroleum Agency (ANP 2011), in 2010 biodiesel production in Brazil was approximately $2.4 \mathrm{bi}-$ llion of liters and for every 50 gallons of biodiesel approximately 4 to $5 \mathrm{~kg}$ of its co-residual product, glycerol, are generated (He and Thompson 2006). Glycerol (propane-1,2,3-triol) is an organic compound belonging to

Accepted: 13.06.2013.

* vivian_osbio@yahoo.com.br the alcohol function, liquid at room temperature $\left(25^{\circ} \mathrm{C}\right)$, hygroscopic, odorless, viscous and presenting sweet taste (IUPAC $1993^{1}$, cited Menten ${ }^{2}$ et al 2009).

The recent surge in the use of biodiesel in Brazil and abroad, coupled with the availability of large amounts of glycerol, are generating interest in the use of this coproduct in several ways, among them, its application in animal feed. The U.S. legislation assigned to glycerol GRAS status (Generally Recognized as Safe) for use as a food additive according to good manufacturing standards and food, including for humans (FDA 2006).

The use of glycerol in the formulation of diets stimulated immediate interest to obtain a rich in energy product

IUPAC, International Union of Pure and Applied Chemistry. 1993. www.iupac.org. Visitado noviembre 2011.

2 Menten JFM, VS Miyada, B Berenchtein. 2009. Glicerol na Alimentação Animal. www.agrolink.com.br/downloads/glicerol_2009-03-13.pdf. Visitado noviembre 2011. 
(4320 kcal gross energy per kg of pure glycerol) and high efficiency of utilization by animals (Berenchtein et al 2010). Moreover, serving as an energy source, glycerol may also have a positive effect on nitrogen retention, improving the recovery of amino acids and reducing the emission of pollutants in the enviroment (Cerrate et al 2006, Berenchtein et al 2010). Several studies involving pigs (Della Casa et al 2009, Seneviratne et al 2011), cattle (Wang et al 2009a, Wang et al 2009 , Abo El-Nor et al 2010) and sheep (Terre et al 2011), have been developed to determine the effects of glycerol from different sources on performance, meat and milk quality and digestibility of nutrients.

Glycerol is a normal component of animal metabolism, it is produced by lipolysis of adipose tissue or blood lipoproteins. However, there is no agrement on the metabolic implications of exogenous supplementation of glycerol in the diet, particularly when supplementation becomes the major energy ingredient of the diet. Additionally, protocols for adequate supplementation for different species are unknown.

Thus, the objective of this study was to evaluate the effects of the use of glycerol resulting from biodiesel production as energy supplement in animal feed production, to establish appropriate protocols for each species from previous studies.

\section{MATERIAL AND METHODS}

\section{RESEARCH STRATEGY}

An electronic search of the database Science Direct ${ }^{3}$ was carried out in October 2011 using the following keywords: glycerol and biodiesel, and food and nutrition. To confirm the results and obtain additional studies, a similar strategy was used in Pubmed ${ }^{4}$, ISI Web of Science ${ }^{5}$ and Scielo ${ }^{6}$ databases, using the same keywords in Portuguese and Spanish, when applicable.

\section{SELECTION OF STUDIES}

Studies in which glycerol was used as nutrient for animal feed production were selected. There was no restriction for animal species, sample size, dose and period of administration of glycerol. Additionally, there was no restriction on date or language for the selected articles.

\section{DATA COLLECTION}

Two researchers conducted the searches separately, taking care that the work conforms to the criteria selected

\footnotetext{
WwW.sciencedirect.com

www.ncbi.nlm.nih.gov

http://apps. isiknoledge.com

www.scielo.org/php/index.php
}

for inclusion. In case of any discrepancy between the documents, all criteria were reviewed and discussed. Table 1 shows the data related to the experimental design of the retrieved articles.

\section{QUALITY CRITERIA}

The criteria were adapted based on other systematic reviews (Noli et al 2005, Negre et al 2009, Pereira et al 2011). The parameters used were:

- Randomization: randomized trials received score 2, whereas non-randomized experiments or when this fact was not clearly described in the text received a score 1 .

- Blind Assessment: experiments in which evaluation was performed by a blind examiner received score 2 ; when this fact was not clearly described in the text it received a score 1 .

- Control group: studies that used control groups received score 2 and studies that control groups were not mentioned in the text received a score 1 .

- sample size: the number of repetitions were determined according to the species: pig (less than 3 animals - a score 1, between 3 and 6 - score 2 and above 6 animals per group - score 3 ), birds (less than 10 - score 1 , between 10 and 20 - score 2 and above 20 - score 3 ), cattle and sheep (less than 10 - score 1; between 10 and 20 - score 2 and above 20 - score 3 ).

- Quality parameters evaluated: studies performing molecular analyzes or ELISA / RIA received score 2, those which underwent other types of analyzes (colorimetric / enzymatic, substrate analysis, milk and eggs, performance, etc) received score 1 ;

The maximum total score was 11 points.

Additional variables such as species, breed, experimental period, collected material, among others, were used for descriptive purposes only, without punctuation, in order to contribute to the discussion (table 1).

\section{RESULTS}

The search using ISI Web of Science database resulted in 132 articles, 38 were excluded for dealing with glycerol production, three were excluded because used in vitro essays, nine for not using glycerol in the diet (experiments with other products), 40 articles were literature reviews and 27 did not fit in the selection criteria (book chapter, book index, summary of congress, etc.). Thus, 15 out of 132 articles were selected for this study.

The search in PubMed database resulted in two additional articles. The research done in the ISI Web of Science Scielo databases did not result in additional articles. Therefore, we selected 17 articles for this review (table 2).

Retrieved studies had been carried out on pigs, cows, bulls, sheep, laying hens and broilers. Sample sizes varied widely among articles, a fact that may have occurred due to the variety of species and different statistical 


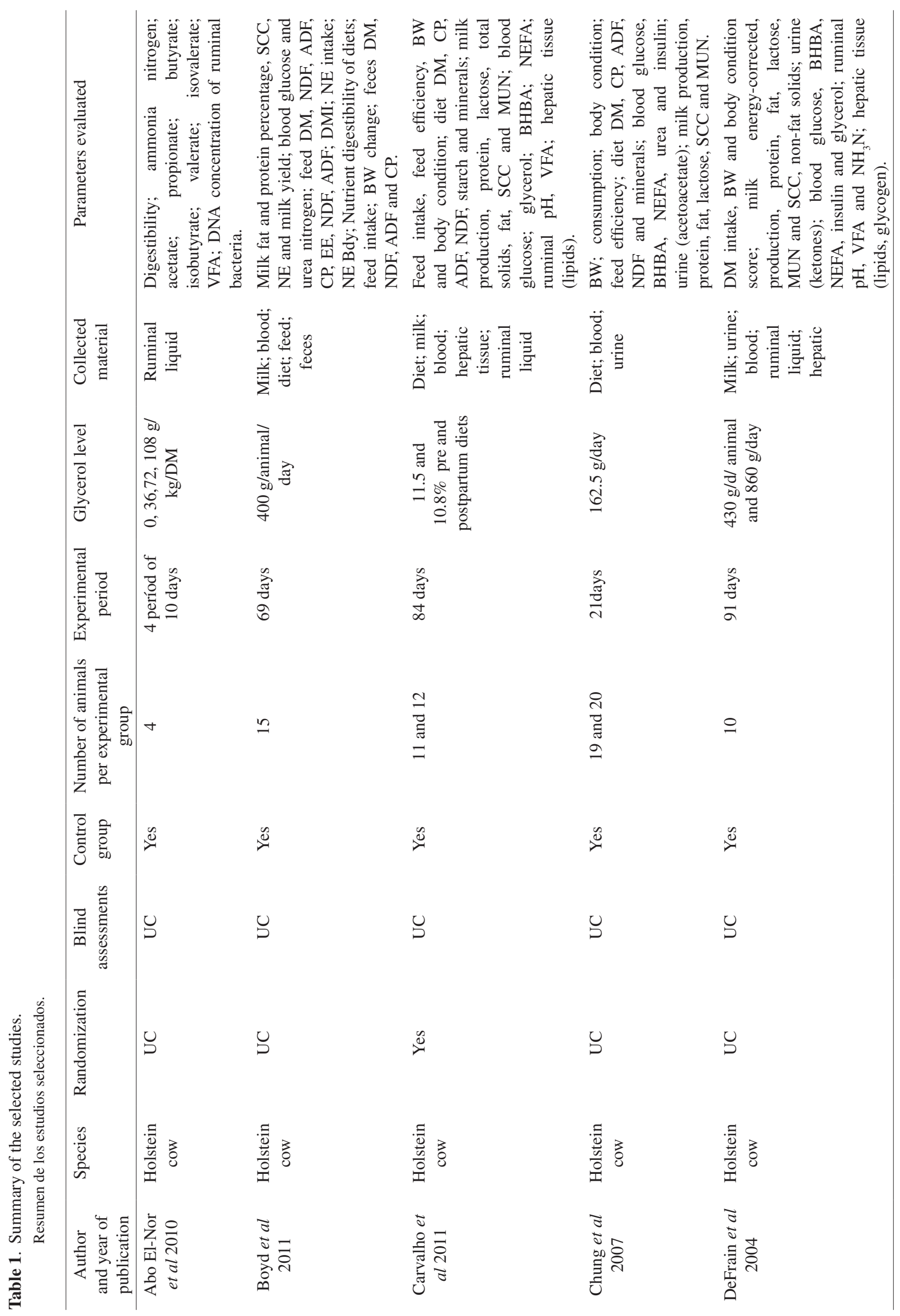




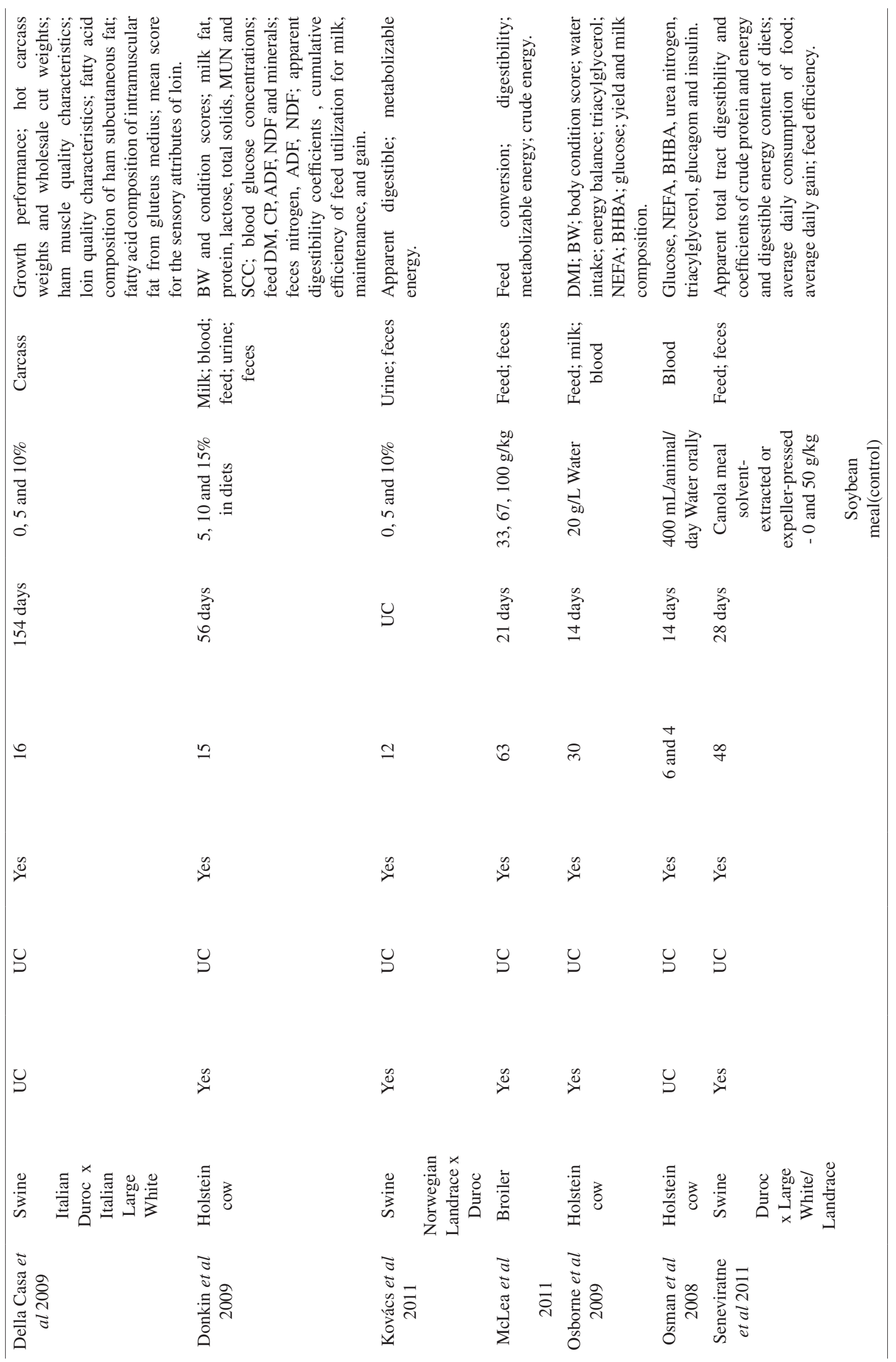




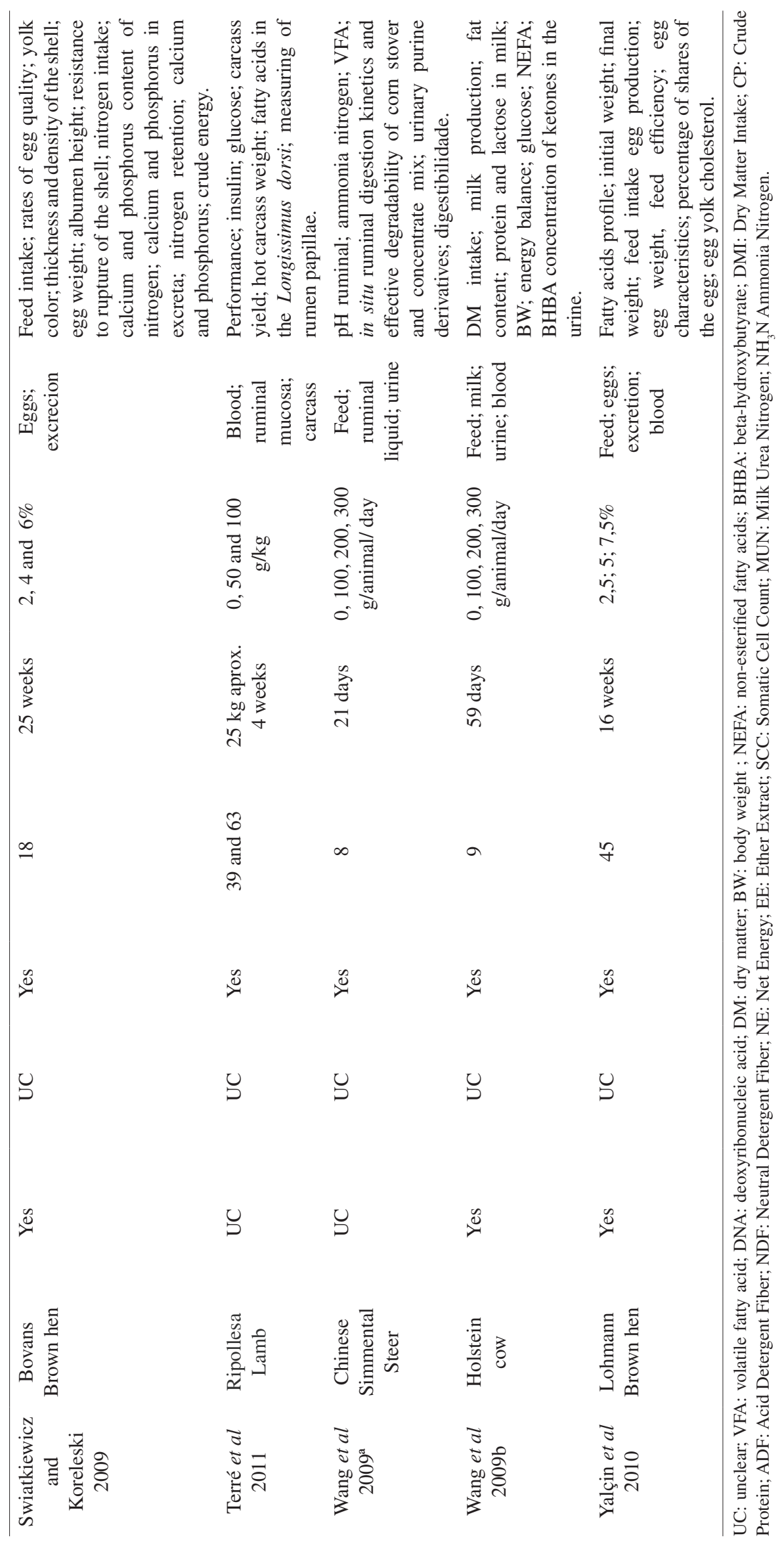


Table 2. Scores for evaluation criteria of articles selected.

Puntuaciones de los criterios de evaluación de los artículos seleccionados.

\begin{tabular}{|c|c|c|c|c|c|c|}
\hline Author & Randomization* & $\begin{array}{c}\text { Blind } \\
\text { assessments** }\end{array}$ & $\begin{array}{l}\text { Control } \\
\text { group } * * *\end{array}$ & $\begin{array}{l}\text { Sample } \\
\text { number+ }\end{array}$ & $\begin{array}{c}\text { Quality parameters } \\
\text { evaluated++ }\end{array}$ & Total \\
\hline McLea et al 2011 & 2 & 1 & 2 & 3 & 1 & 9 \\
\hline Seneviratne et al 2011 & 2 & 1 & 2 & 3 & 1 & 9 \\
\hline Terré et al 2011 & 1 & 1 & 2 & 3 & 2 & 9 \\
\hline Yalçin et al 2010 & 2 & 1 & 2 & 3 & 1 & 9 \\
\hline Osborne et al 2009 & 2 & 1 & 2 & 3 & 1 & 9 \\
\hline Carvalho et al 2011 & 2 & 1 & 2 & 2 & 1 & 8 \\
\hline Kovács et al 2011 & 2 & 1 & 2 & 2 & 1 & 8 \\
\hline Abo El-Nor et al 2010 & 1 & 1 & 2 & 2 & 2 & 8 \\
\hline Donkin et al 2009 & 2 & 1 & 2 & 2 & 1 & 8 \\
\hline Wang et al $2009^{\mathrm{b}}$ & 2 & 1 & 2 & 2 & 1 & 8 \\
\hline Osman et al 2008 & 1 & 1 & 2 & 2 & 2 & 8 \\
\hline $\begin{array}{l}\text { Swiatkiewicz and } \\
\text { Koreleski, } 2009\end{array}$ & 2 & 1 & 2 & 2 & 1 & 8 \\
\hline Chung et al 2007 & 1 & 1 & 2 & 3 & 1 & 8 \\
\hline DeFrain et al 2004 & 1 & 1 & 2 & 2 & 2 & 8 \\
\hline Boyd et al 2011 & 1 & 1 & 2 & 2 & 1 & 7 \\
\hline Della Casa et al 2009 & 1 & 1 & 2 & 2 & 1 & 7 \\
\hline Wang $2009^{\mathrm{a}}$ & 1 & 1 & 2 & 2 & 1 & 7 \\
\hline
\end{tabular}

* Nonrandomized experiments or when randomization was not described clearly in the text (score 1) and randomized experiments (score 2).

** Experiments without blind assessments or those in which blind assessments were not clearly reported in the text (score 1) and experiments with blind assessments (score 2).

*** Studies without control groups or those which did not clearly mention a control group in the text (score 1) and studies with a control group (score 2).

+ Sample size scores were determined according to the species: pig (less than 3 animals - score 1, between 3 and 6 , score 2 and 6 above, score 3 ), birds (less than 10 , score 1 , between 10 and 20, scores 2 and above 20, score 3 ), cattle and sheep (less than 10 , score 1 ; between 10 and 20 , scores 2 and above 20, score 3).

++ Research protocols that performed molecular or ELISA/RIA analyzes received score 2, those which underwent other types of analyzes (colorimetric/enzymatic, substrate analysis, milk and eggs, performance only, etc) received score 1.

designs used. Seventy percent of the studies conducted randomized trials. All articles included a control group, but none of them have declared blind evaluations.

Glycerol was fed to animals in $88 \%$ of the selected articles, while in $12 \%$ of them it had been administered in water. There was a large variation in the level of glycerol supplied, without a pattern even within the same species. The time of administration of glycerol also varied greatly (ten days to 25 weeks).

In experiments performed with bovines, the most frequently collected materials for laboratory analysis were: blood, food and milk. In pigs, the collection of faeces was the most commonly assessed parameter due to digestibility analyses. Excreta were also collected in three experiments with birds in order to evaluate the nitrogen, calcium and phosphorus content, food intake and digestibility. In one experiment conducted with lambs, ruminal mucosa, blood and carcass were collected.

Glycerol is classified according to its purity; in gene- ral, crude glycerol contains about $80 \%$ purity; technical glycerol has a purity exceeding $90 \%$ and pharmaceuticalgrade glycerol has purity higher than $99.7 \%$ (Vincent $e t$ al 2010). Products with lower purity, as in the case of crude glycerol, may present contaminants originating from the extraction process, such as methanol, a toxic substance which is considered unsafe at levels above 150 ppm (Dasari 2007). However, pigs fed diets containing glycerol and 2,900 ppm (Hansen et al 2009) and 3,200 ppm (Lammers et al 2008) of methanol showed no signs of intoxication. Out of the 17 studies used in this review, seven $(41 \%)$ used glycerol with purity between 65 and 90\%; seven (41\%) reported the use of glycerol between $90 \%$ and $99.7 \%$ purity and three $(18 \%)$ used products with a purity greater than $99.7 \%$. Regarding the levels of methanol, only three studies reported specific amounts of this substance - 1.2\% (DeFrain et al 2004); 0.05\% (Terré et al 2011, Kovacs et al 2011). Some other studies reported non-significant levels of methanol. 
The replacement of 5\% of the dietary energy source by glycerol did not modify the in vivo or at slaughtering performance in pigs (Della Casa et al 2009). Similar results were observed in lambs after about four weeks (Terre et al 2011). However, a substitution of $10 \%$ caused growth and feed efficiency deterioration (Della Casa et al 2009). In pigs, the addition of glycerol in the diet did not affect the average daily consumption, average daily weight gain or feed efficiency, in a period of 0-28 days, initiated seven days after weaning (Seneviratne et al 2011).

The performance of dairy cows was variable, particularly in relation to food intake. Some authors have reported that the use of glycerol reduced the dry matter intake. Defrain et al (2004), evaluating animals in the pre-birth, found that levels of glycerol from approximately 2.7 to $5.4 \%$ (430 g/day and $860 \mathrm{~g} /$ day) reduced dry matter intake by $17 \%$. Similar results were obtained by Osborne et al (2009) in cows fed with diets containing up to about $13 \%$ glycerol ( $800 \mathrm{~g} /$ day to $1600 \mathrm{~g} /$ day) and soybean oil in water, during the pre-delivery and postpartum. Donkin et al (2009) also found a reduction in feed intake during the first seven days of use in diets containing $15 \%$ of glycerol in dry matter. On the other hand, diets with 10.8 and $11.5 \%$ glycerol during 28 days before calving until 56 days postpartum (Carvalho et al 2011), approximately 0.6 to $1.9 \%$ (100 g/day $200 \mathrm{~g} /$ day and $300 \mathrm{~g} /$ day) for 59 days postpartum (Wang et al 2009 ), or raw glycerin containing approximately $0.7 \%$ glycerol (162.5 g/day) for 21 days post- delivery (Chung et al 2007), did not cause deleterious effects on feed intake and milk production (Chung et al 2007, Donkin et al 2009, Wang et al

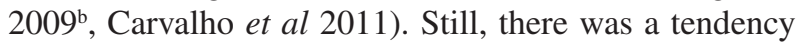
to increase milk production in cows supplemented with glycerol during the sixth week of lactation, probably due to changes in metabolism (DeFrain et al 2004). Regarding the composition of milk, no differences were found with the use of up to $13 \%$ glycerol (Donkin et al 2009, Osborne et al 2009, Carvalho et al 2011). There was only a subtle reduction in the levels of milk fat and protein within 63 days of early lactation, even when using $1.9 \%$ $(300 \mathrm{~g} / \mathrm{d})$ glycerol in dry matter (Wang et al $2009^{\mathrm{b}}$ ).

In chickens, the use of glycerol up to $7,5 \%$ did not affect body weight, and weight of egg production and feed efficiency (Yalcin et al 2010). The egg quality parameters were not changed (Swiatkiewicz and Koreleski 2008, Yalcin et al 2010). Moreover, the inclusion of glycerol obtained from soybean biodiesel production, at $5 \%$ and $7.5 \%$ increased cholesterol content of the egg yolk, increased the percentage of myristic, palmitic, palmitoleic and linolenic acids and reduced the percentage of oleic acid, compared to eggs of hens fed with control diet. The total monounsaturated fatty acids of egg yolk were lower only in animals fed with the diet containing $7.5 \%$ of glycerol compared to the control group (Yalcin et al 2010).
The addition of glycerin in the diet caused no significant effect when evaluating parameters such as carcass yield (Della Casa et al 2009, Terre et al 2011), lean content and weight and lean cuts (Della Casa et al 2009),. Additionally, no effect on fatty acid composition (Terre et al 2011) and intramuscular fatty acids (Della Casa et al 2009) were found. Higher doses of glycerol resulted in higher octadecenoic acid content and a trend towards lower levels of palmitic, stearic and linoleic acids (Della Casa et al 2009).

Glycerol has also influenced the pattern of rumen fermentation. Its use in about 3.3\% (100g/day, $200 \mathrm{~g} / \mathrm{day}$ and $300 \mathrm{~g} /$ day) caused a linear increase in the concentration of volatile fatty acids in the rumen of calves, especially propionate (Wang et al 2009a). These changes in fermentation profile were also found in lactating cows, while increasing proportions of propionate and butyrate (DeFrain et al 2004, Abo El-Nor et al 2010), valerate (Abo El-Nor et al 2010) and isovalerate with reduction in the proportion of acetate (DeFrain et al 2004, Abo El-Nor et al 2010).

Studies also reported the effects of glycerol in the digestion process. The use of glycerol in the levels of $1.11 \%$ to $3.33 \%$ (100 g/day, $200 \mathrm{~g} /$ day and $300 \mathrm{~g} /$ day) increased ruminal degradation of Neutral Detergent Fiber (NDF) of corn stover, digestibility and urinary excretion of purine derivatives (Wang et al 2009a). Supplementation at levels close to $1.5 \%$ (400 g/day) in dry matter during lactation also increased apparent digestibility of dry matter and Acid Detergent Fiber (ADF), during lactation (Boyd et al 2011). However, other studies have reported that the addition of up to $10.8 \%$ glycerol did not alter the measurements of rumen papillae (Terre et al 2011), fermenting bacteria in the rumen, the concentration of ammonia nitrogen and dry matter digestibility (Abo El-Nor et al 2010). There was a lower degradability of protein with use of $0.6 \%$ to $1.9 \%$ (100g/day $200 \mathrm{~g} /$ day and 300 g/day) glycerol (Wang et al 2009a) and reduction of NDF digestibility and concentration Butyrivibrio fibrisolvens and Selenomonas ruminantium at the inclusion levels of 7.2 and $10.8 \%(72 \mathrm{~g} / \mathrm{kg}$ and $108 \mathrm{~g} / \mathrm{kg})$ glycerol in the diet from bovines (Abo El-Nor et al 2010).

With regard to digestibility of nutrients and energy, the use of glycerol up to $10 \%$ in the diet did not influence the digestible and metabolizable energy in pigs (Kovács et al 2011). Moreover, in canola meal diets Solventextracted and Expeller-pressed also for pigs, glycerol increased digestible energy content (Seneviratne et al 2011). In birds, ammonia, calcium and phosphorus levels in excreta were not affected by adding glycerin (Swiatkiewicz et al 2008).

With regard to metabolic effects, in cows there was an increase in blood glucose (Chung et al 2007, Osman et al 2008, Wang et al 2009 ) and insulin (Osman et al 2008), reduction of serum $\beta$-hydroxybutyrate (Chung et al 2007, Osman et al 2008, Osborne et al 2009, Wang et al 2009 ) and non-essential fatty acids in the blood (DeFrain et al 
2004, Osman et al 2008, Wang et al 2009 ), and reduction of ketones in urine (Chung et al 2007, Wang et al $\left.2009^{b}\right)$. These results were correlated with glycerol levels ranging from about 0.7 to $13 \%$ (162.5 g / day to $1600 \mathrm{~g}$ / day) in dry matter and for periods between 14-60 days. However, in other studies, supplementation up to $13 \%$ (or up to $1600 \mathrm{~g} / \mathrm{d}$ ) glycerol did not affect the concentration of glucose or insulin in cows and in lambs respectively (DeFrain et al 2004, Osborne et al 2009). Glycerol levels above $13 \%$ did not affect the concentrations of nonessential fatty acids in cows (Osborne et al 2009) and total protein, uric acid, triglycerides, cholesterol, alanine aminotransferase, aspartate amino transferase and alanima phosphatase in hens (Yalcin et al 2010). Additionally, the use of an average level of glycerol near to 5,4\% dry matter (860 g/day) in cow diets, reduced glucose and $\beta$-hydroxybutyric acid increase in plasma for a period of seven to 21 days of lactation (DeFrain et al 2004).

Regarding metabolizable energy (ME), Kovács et al (2011) found that including glycerol $(86.76 \%$ purity) in the diet of growing pigs, provided $3,218 \mathrm{kcal} / \mathrm{kg}$ of energy. For finishing pigs, the addition of $30 \%$ glycerol with a purity of $97.5 \%$, the ME was $3,723 \mathrm{kcal} / \mathrm{kg}$ (Mendoza et al 2010). For chickens aged between 7 and 10 days, a diet containing from $3 \%$ to $6 \%$ glycerol showed ME values of $3,621 \mathrm{kcal} / \mathrm{kg}$, turning to $3,331 \mathrm{kcal} / \mathrm{kg}$ and $3,349 \mathrm{kcal} /$ $\mathrm{kg}$, for chickens aged between 21-24 days and between 42-45 days of life respectively (Dozier et al 2007). Also in chickens, it was found that the ME values of feeds containing glycerol were 3,598, 4,911 and 3,777 kcal / $\mathrm{kg}$ for diets containing $70 \%$ glycerol from soybean oil, $9.92 \%$ from mixture of frying oil and lard and $79.32 \%$ (from semi-purified process) respectively (Lima et al 2012). Considering the high digestibility of glycerol in the diet of chickens, Cerrate et al (2006) assumed the value of 3,527 $\mathrm{kcal} / \mathrm{kg}$ based on the gross value obtained from the calorimetric bomb $(3,596 \mathrm{kcal} / \mathrm{kg}$ of $\mathrm{ME}$ for glycerol with purity between $2.5 \%$ and $10 \%$ ), however the inclusion of $10 \%$ caused negative effects on the performance of these animals. Thus, a better understanding of the correlation between the purity of glycerol and its role as source of dietary energy will allow the formulation of balanced diets in order to improve animal production performance (Alvarenga et al 2012).

\section{DISCUSSION}

Systematic reviews can promote much insight into the scientific community in general, since they allow a more complete and clear view of the results from different studies in the same field and also suggest the best protocols to be used and / or searched. Study limitations should be highlighted as some publications may not have been retrieved due to the different title and keyword indexes, although the authors have endeavored to ensure that no article was excluded. It may also be mentioned that the assessment of methodological quality was based on previous research and experience of the authors.

In order to produce a quality evaluation, we used defined criteria such as presence or absence of randomization, blind assessment of measurements, presence of a control group, sample size, etc. These evaluations were of great importance in this study in order to contribute in characterisation of the study, classifying them according to their attributes and their statistical analyses. As an example, blind and randomized evaluations are of great importance to bring greater reliability to scientific work, since it prevents study participants to know which treatment is being applied. In the case of randomized trials, the distribution is made randomly (Pereira et al 2011).

The conduction of this study yielded results with large amplitude both with respect to the species addressed, such as the protocols used in the supplementation of glycerol. For a given species, there were considerable variations in the level of glycerol and the administration period.

Considering the performance of animals, starting with dairy cows, there was no consensus among authors mainly in relation to consumption. Some authors have suggested a reduction in food intake using varying levels of glycerol (intervals between approximately $2.7 \%$ and $15 \%$ dry matter) (DeFrain et al 2004, Donkin et al 2009, Osborne et al 2009), whereas others using similar levels found no such effects on consumption (ranges between $0.6 \%$ and $11.5 \%$ glycerol in dry matter) (Chung et al 2007, and Swiatkiewicz Koreleski 2009, Carvalho et al 2011). In the production and composition of milk there was greater consensus among authors, since most of them found no deleterious effects on these parameters (Chung et al 2007, Donkin et al 2009, Osborne et al 2009, Wang et al 2009', Carvalho et al 2011). In general, no changes in performance levels up to approximately $7.5 \%$ of glycerol were found in poultry and pigs and sheep (Della Casa et al 2009, Swiatkiewicz and Koreleski 2009, Yalcin et al 2010, Terre et al 2011). However, using about $10 \%$ in pigs, some detrimental effects on their growth were reported (Della Casa et al 2009) and at levels of 5\% to $7.5 \%$ for birds the composition of eggs, especially in relation to the yolk were altered (Yalcin et al 2012).

The digestion process seems to be altered or at least influenced by the use of glycerol in different species. In cattle the pattern of ruminal fermentation was modified, however, there was no agreement regarding the obtained results. Glycerol can provide cattle with some benefits such as increased fiber degradation and dry matter digestibility in steers when used at levels ranging $1.11 \%$ to $3.33 \%$ (Wang et al 2009), however, it can also negatively affect the degradation of crude protein in dairy cows (Wang et al 2009 b), and also according to Abo El-Nor et al (2010) it reduces NDF digestibility, negatively affecting the process of digestion. In pigs and poultry, glycerol did not bring major changes in relation to digestibility (Swiatkiewicz and Koreleski 2009, Kovács et al 2011). 
The metabolic effects of glycerol influenced biochemical parameters and hormone release in blood and urine. However, there was great variability in results. The supply of glycerol of about $0.7 \%$ to $13 \%$ in dry matter increased the availability of energy in some studies (Chung et al 2007, Osman et al 2008, Wang et al 2009'), but did not change it in others (glycerol in the diet about up to $13 \%$ dry matter) (DeFrain et al 2004, Osborne et al 2009, Terre et al 2011), while it decreased in additional studies (glycerol in the diet up to $5.4 \%$ of dry matter), increasing the susceptibility to ketosis during lactation in cows (DeFrain et al 2004). This diversity of results may be due to factors such as the wide variability in levels of glycerol supplied, periods of administration and interference of simultaneous treatment in animals. Besides, these differences among species in relation to age, weight and race were very important, generating mixed results and making comparison difficult.

Based on the analysis of results on animal performance and the quality of milk, eggs and carcasses, no harmful changes to animals were found. The range of scores among the retrieved articles was only two points, with nine being the highest score.

Since some studies may possibly have not been retrieved because of the search strategy used in this review, new systematic reviews are encouraged using other terms (such as glycerin) related to biodiesel components in order to produce more reliable data regarding its use in animal feeding.

Based on selected studies for laying hens, it can be concluded that the addition of up to $6 \%$ of glycerol in diet did not influence the egg quality parameters when administered up to 16 weeks. In pigs, the replacement of an energy source up to $5 \%$ of glycerol in the diet did not seem to alter the performance of animals. In cattle, especially lactating cows, adding up to $15 \%$ of glycerol in the diet did not affect negatively their metabolism, performance or production. Therefore, glycerol may be a food ingredient suitable for replacement in diets for different animal species.

\section{ACKNOWLEDGEMENT}

This work was financially supported by FAPEMIG (Research Sponsoring Agency of the State of Minas Gerais) and CNPq (National Counsel of Technological and Scientific Development).

\section{REFERENCES}

Abo El-Nor S, AA Abughazaleh, RB Potu, D Hastings, MSA Khattab. 2010. Effects of differing levels of glycerol on rumen fermentation and Bacteria. Anim Feed Sci Technol 162, 99-105.

Alvarenga RR, EMC Lima, MG Zangeronimo, PB Rodrigues, Bernardino VMP. 2012. Use of glycerine in poultry diets.
World Poultry Sci J, 68, 637-644.

ANP, Agência Nacional do Petróleo, Gás Natural e Biocombustíveis. 2009. Resolução Conselho Nacional de Política Energética $N^{\circ}$ 6, de 16.9.2009.

ANP, Agência Nacional do Petróleo, Gás Natural e Biocombustíveis. 2011. Biocombustíveis: Biodiesel.

Berenchtein B, LB Costa, DB Braz, VV Almeida, MLP Tse, VS Miyada. 2010. Utilização de glicerol na dieta de suínos em crescimento e terminação. R Bras Zootec 39, 1491-1496.

Boyd J, JW West, JK Bernard. 2011. Effects of the addition of direct-fed microbials and glycerol to the diet of lactating dairy cows on milk yield and apparent efficiency of yield. J Dairy Sci 94, 4616-4622.

Carvalho ER, NS Schmelz-Roberts, HM White, PH Doane, SS Donkin. 2011. Replacing corn with glycerol in diets for transition dairy cows. J Dairy Sci 94, 908-916.

Cerrate S, F Yan, Z Wang, C Coto, P Sacakli, PW Waldroup. 2006. Evaluation of glycerine from biodiesel production as a feed ingredient for broilers. Int J Poult Sci 5, 1001-1007.

Chung YH, DE Rico, CM Martinez, TW Cassidy, V Noirot, A Ames, GA Varga. 2007. Effects of feeding dry glycerin to early postpartum Holstein dairy cows on lactational performance and metabolic profiles. J Dairy Sci 90, 5682-5691.

Dasari M. 2007. Crude glycerol potential described. Feedstufs 79, 1-3.

DeFrain JM, AR Hippen, KF Kalscheur, PW Jardon. 2004. Feeding glycerol to transition dairy cows: effects on blood metabolites and lactation performance J Dairy Sci 87, 4195-4206.

Della Casa G, D Bochicchio, V Faeti, G Marchetto, E Poletti, A Rossi, A Garavaldi, A Panciroli, N Brogna. 2009. Use of pure glycerol in fattening heavy pigs. Meat Sci 81, 238244.

Donkin SS, SL Koser, HM White, PH Doane, MJ Cecava. 2009. Feeding value of glycerol as a replacement for corn grain in rations fed to lactating dairy cows. J Dairy Sci 92, 5111-5119.

Dozier WA, BJ Keer, A Corzo, MT Kidd, TE Weber, K Bregendahl. 2007. Apparent metabolizable energy of glycerin for broiler chickens. Poult Sci, 87, 317-322.

FDA, Food and Drug Administration. 2006. Substances generally recognized as safe: general purpose food additivesglycerin. Code of Federal Regulations.

Hansen CF, A Hernandez, BP Mullan, K Moore, M TrezonaMurray, RH King, JR Pluske. 2009. A chemical analysis of samples of crude glycerol from the production of biodiesel in Australia, and the effects of feeding crude glycerol to growing-finishing pigs on performance, plasma metabolites and meat quality at slaughter. Anim Prod Sci, 49, 154-161.

Kovács P, E Zsédely, A Kovács, G Virág, J Schmidt. 2011. Apparent digestible and metabolizable energy content of glycerol in feed of growing pigs. Livest Sci 142, 229-234.

Lammers PJ, BJ Kerr, TE Weber, K Bregendahl, SM Lonergan, KJ Prusa, DU Ahn, WC Stoffregen, WA Dozier, MS Honeyman. 2008. Growth performance, carcass characteristics, meat quality, and tissue histology of growing pigs fed crude glicerine-supplemented diets. J Anim Sci, 82, 62-70.

Lima EMC, PB Rodrigues, RR Alvarenga, VMP Bernardino, L Makiyama, RR Lima, VS Cantarelli, MG Zangerônimo. 
2012. The energy value of biodiesel glycerine products fed to broilers at different ages. J Anim Physiol Anim Nutr, DOI: 10.1111/j.1439-0396.2012.01335.x

McLea L, MEE Ball, D Kilpatrick, C Elliott. 2011. The effect of glycerol inclusion on broiler performance and nutrient digestibility. Br Poult Sci 52, 368-375.

Mendonza OF, M Ellis, FK McKeith, AM Gaines. 2010. Metabolizable energy content of refined glycerin and its effects on growth performance and carcass and pork quality characteristics of finishing pigs. J Anim Sci, 88, 3887-3895.

Menten JFM, VS Miyada, B Berenchtein. 2009. Glicerol na Alimentação Animal. Disponível em: <http://www.agrolink.com.br/downloads/glicerol_2009-03-13.pdf>. Acesso em: 11/2011.

Negre A, E Bensignor, J Guillot. 2009. Evidence-based veterinary dermatology: a systematic review of interventions for Malassezia dermatitis in dogs. Vet Dermatol 20, 1-12.

Noli C, ST Auxilia. 2005. Treatment of canine Old World visceral leishmaniasis: a systematic review. Vet Dermatol 16, 213-232.

Osborne VR, NE Odongo, JP Cant, KC Swanson, BW McBride. 2009. Effects of supplementing glycerol and soybean oil in drinking water on feed and water intake, energy balance, and production performance of periparturient dairy cows. J Dairy Sci 92, 698-707.

Osman MA, PS Allen, NA Mehyar, G Bobe, JF Coetzee, KJ Koehler, DC Beitz. 2008. Acute metabolic responses of postpartal dairy cows to subcutaneous glucagon injections, oral glycerol, or both. J Dairy Sci 91, 3311-3322.

Pereira UP, DGS Oliveira, LR Mesquita, LJ Pereira. 2011. Efficacy of Staphylococcus aureus vaccines for bovine masti- tis: A systematic review. Vet Microbiol 148, 117-124.

Seneviratne RW, E Beltranena, LA Goonewardene, RT Zijlstra. 2011. Effect of crude glycerol combined with solvent-extracted or expeller-pressed canola meal on growth performance and diet nutrient digestibility of weaned pigs. Anim Feed Sci Tech 170, 105-110.

Swiatkiewicz S, J Koreleski. 2009. Effect of crude glycerin level in the diet of laying hens on egg performance and nutrient utilization. Poult Sci 88, 615-619.

Terré M, A Nudda, P Casado, A Bach. 2011. The use of glycerine in rations for light lamb during the fattening period. Anim Feed Sci Tech 164, 262-267.

Thompson JC, BB He. 2006. Characterization of crude glycerol from biodiesel production from multiple feedstocks. Appl Eng Agric 22, 261-265.

Vicente G, JA Melero, G Morales, M Paniagua, E Martín. 2010. Acetalisation of bio-glycerol with acetone to produce solketal over sulfonic mesostructured silicas. Green Chem 12, 899-907.

Wang C, Q Liu, WJ Huo, WZ Yang, KH Dong, YX Huang, G Guo. 2009a. Effects of glycerol on rumen fermentation, urinary excretion of purine derivatives and feed digestibility in steers. Livest Sci 121, 15-20.

Wang C, Q Liu, WZ Yang, WJ Huo, KH Dong, YX Huang, XM Yang, DC He. 2009 ${ }^{\mathrm{b}}$. Effects of glycerol on lactation performance, energy balance and metabolites in early lactation Holstein dairy cows. Anim Feed Sci Tech 151, 12-20.

Yalçin S, H Erol, B Özsoy, İ Onbaşılar, S Yalçın, A Üner. 2010. Effects of glycerol on performance, egg traits, some blood parameters and antibody production to SRBC of laying hens. Livest Sci 129, 129-134. 